Table 1

\begin{tabular}{|c|c|c|c|c|c|c|c|c|c|c|c|c|}
\hline & \multirow{2}{*}{\multicolumn{2}{|c|}{$\begin{array}{l}\text { Alcohol, } \mathrm{C}_{30} \mathrm{H}_{60} \mathrm{O}, \\
\text { from linseed oil }\end{array}$}} & \multicolumn{10}{|c|}{ Data quoted by : } \\
\hline & & & \multicolumn{2}{|c|}{ Barton (ref. 1) } & \multicolumn{2}{|c|}{ Spring (refs. 2, 3) } & \multicolumn{2}{|c|}{ Gonzales (ref. 10) } & \multicolumn{2}{|c|}{ Chapon (ref. 11) } & \multicolumn{2}{|c|}{ Shimizu (ref. 6) } \\
\hline & m.p. & {$[\alpha]_{D}$} & m.p. & {$[\alpha]_{D}$} & m.p. & {$[\alpha]_{D}$} & m.p. & {$[\alpha]_{D}$} & m.p. & {$[a]_{D}$} & m.p. & {$[a]_{D}$} \\
\hline $\begin{array}{l}\text { Alcohol } \\
\text { Acetate }\end{array}$ & $\begin{array}{l}115-116 \\
121-122\end{array}$ & $\begin{array}{l}+51 \cdot 4 \\
+60 \cdot 2\end{array}$ & $\begin{array}{l}85-92 \\
122 \cdot 5 \\
123 \cdot 5\end{array}$ & $\begin{array}{l}+48 \\
+58\end{array}$ & $\begin{array}{c}115 \\
122-124\end{array}$ & $\begin{array}{l}+54 \\
+59 \cdot 5\end{array}$ & $\begin{array}{l}97-112 \\
118 \cdot 2\end{array}$ & $\begin{array}{l}+47 \\
+54\end{array}$ & $\begin{array}{r}80-105 \\
119-120\end{array}$ & $\begin{array}{l}+48 \cdot 5 \\
+58\end{array}$ & $\begin{array}{l}114-115 \\
122-124\end{array}$ & $\begin{array}{r}+52 \\
+59\end{array}$ \\
\hline Benzoate & $129-130$ & +68 & $129-130$ & +65 & 130 & +76 & 129 & +54 & 130 & +67 & $129-130$ & +75 \\
\hline
\end{tabular}

isolated, by chromatography of the neutral? unsaponifiable of a linseed oil of Italian production on silicic acid, a group of materials characterized by a yellow. brown Liebermann-Burchard reaction. Paper chromatography ${ }^{8}$ shows the presence in this fraction of three different substances at least, probably terpenic alcohols. Subsequent chromatography of the fraction on aluminium oxide made it possible to isolate, by elution with hexane-benzol, a substance which after crystallization from methanol melted at $115-116^{\circ} \mathrm{C}$., $[\alpha]_{D}=+51 \cdot 4^{\circ}$. This substance gave a yellow-brown colour with the Liebermann reagent and a distinct yellow colour with nitromethane ; paper chromatography showed the presence of only one component.

The compound isolated has been characterized through the acetate and the benzoate; in Table 1 are recorded the values of specific rotations and of the melting points, which agree satisfactorily with those obtained for the cyclo-arthenol by the authors mentioned.

Identification has been confirmed through the infra-red spectrum of the compound isolated from linseed oil, which was identical with that reported by Cole $^{9}$ for the cyclo-arthenol. Finally, the mixed melting point of the acetate of the compound, with a sample of genuine acetyl-cyclo-arthenol, kindly supplied by Dr. Spring, did not show any decrease of melting point.

This investigation suggests that triterpenic alcohols of the same group may be present in other animal and vegetable oils, such as olive oil, maize germ oil, peanut oil and tallow oil.

\section{Pompeo Capella}

Stazione Sperimentale Olii e Grassi, Milan.

${ }^{1}$ Barton, D. H. R., J. Chem. Soc., 1444 (1951).

${ }^{2}$ Bentley, H. R., et al., J. Chem. Soc., 3673 (1953).

'Irvine, D. S., et al., J. Chem. Soc., 1316 (1955).

- Bentley, H., et al., J. Chem. Soc., 596, 1607 (1955).

${ }^{6}$ Cox, J. S., et al., J. Chem. Soc., 1384 (1956); 514 (1959).

- Shimizu, M., et al., Pharmacol. Bull., 5, 36, 40 (1957).

7 Jacini, G., et al., Inform. Oléicoles Int., 9, 81 (1960). Capella, P. . Amer Oil Chem Soc. 37,564 (1960).

${ }^{8}$ de Zotti, G., et al., Fette u. Seifen, 61, 1114 (1959).

- Cole, A. R. H., J. Chem. Soc., 3810 (1954).

${ }^{10}$ Gonzales, A. G., et al., An. Soc. Fis. Quim., 49B, 223 (1953).

${ }^{11}$ Chapon, S., et al., Bull. Soc. Chim., 456 (1952).

\section{A Bilatriene Pigment in the Green Terebellid Polychate Eupolymnia heterobranchia (Johnson)}

Eupolymnia heterobranchia (Johnson) is a relatively large terebellid found in mud and under boulders on the Pacific coast of North America. All the specimens that I have found near Friday Harbor, Washington, had a deep green colour. This is due to granules of green pigment deposited in the colomic cells and in the epidermis. The pigment was readily extracted with acidified methanol, gave a good Gmelin reaction, and reacted positively to the zinc bilipurpurin test. demonstrating that it was a bilatriene. The redfluorescent compound obtained in the latter test had a sharp maximum at $625 \mathrm{~m} \mu$ (Unicam), indicating the presence of meso- rather than proto- side chains'. The great resistance of the pigment to concentrated sulphuric acid also distinguished it from biliverdin. In a 5 per cent hydrochloric acid : methanol mixture the absorption spectrum showed peaks at 360 and $675 \mathrm{~m} \mu$, resembling mesobiliverdin hydrochloride (363 and $670 \mathrm{m \mu}$; ref. 1 ).

Mesobiliverdin has been found to occur in only a few animals, and these are all phytophagous insects ${ }^{2}$. The occurrence of a similar pigment in Eupolymnia is interesting in view of the report by Berkeley and Berkeley $^{3}$ that orange-red individuals are sometimes found. It would be most interesting to know whether the appearance of these orange worms is due merely to a lack of the green pigment or, as is just possible, to mesobilirubin or related pigment.

\section{R. Philluips Dales}

Department of Zoology

Bedford College, London, N.W.1.

${ }^{1}$ Lemberg, R., and Legge, J. W., Hematin Compounds and Bile Pigments (New York, 1940).

'Fox, H. M., and Vevers, G., The Nature of Animal Colours (London, 1960 ).

'Berkeley, E., and Berkeley, C., Canadian Pacific Fauna, 9, Annelida, 9,b (2), Polychaeta Sedentaria (Toronto, 1952).

\section{Occurrence of Cyclo-Propene Acids in Some Plants of the Order Malvales}

Sterculrc and malvalic acids are the only fatty acids known to contain a cyclo-propene ring in their structures. From the seed oil of Sterculia foetida (Sterculiaceae), Nunn ${ }^{1}$ isolated sterculic acid $\left(\mathrm{C}_{19}\right)$ and defined its structure. Malvalic acid $\left(\mathrm{C}_{18}\right)$ isolated from Malvaceae by Shenstone and Vickery ${ }^{2}$ has been structurally identified by Macfarlane, Shenstone and Vickery $^{3}$ and Craven and Jeffrey ${ }^{4}$. Afterwards we reported ${ }^{5}$ the occurrence of minor amounts of sterculic acid associated with malvalic acid in the oils from some malvaceous plants. The occurrence of both acids in the seeds of Sterculia foetida and two species of Malvaceae has also been observed by C. R. Smith, jun., T. L. Wilson and K. L. Mikolajezak (private communication).

We have measured the concentrations of malvalic and sterculic acids in the seed and leaf oils of three species from each of the families, Malvaceae and Sterculiaceae. The solvent-extracted oils were saponified under mild conditions, and the total fatty acids were subjected to low-temperature erystallization. The filtrate contained almost all the cyclopropene acids, and saturated acids were absent. Malvalic and sterculic acids were cleanly separated by the method of reversed-phase column chromatography $^{6}$. They were closely preceded by, and some. times merged with, linoleic and oleic acids, respectively. 